\title{
Ocena wpływu stosowania antykoncepcii hormonalnej na występowanie objawów przewlekfej choroby żylnej u młodych kobiet
}

\author{
An assessment of an influence of the hormonal contraception use on the chronic venous disease \\ symptomatology in young females
}

\author{
Julia Graca', Marta Gromada', Paweł Gruchalski', Tomasz Urbanek² \\ 'Koło Naukowe Studenckiego Towarzystwa Naukowego przy Katedrze i Klinice Chirurgii Ogólnej, Naczyń, Angiologii i Flebologii Śląskiego Uniwersytetu \\ Medycznego w Katowicach (Student Research Group of Student Scientific Society at Department of General Surgery, Vascular Surgery, Angiology \\ and Phlebology, Medical University of Silesia, Katowice) \\ 2Katedra i Klinika Chirurgii Ogólnej, Naczyń, Angiologii i Flebologii Śląskiego Uniwersytetu Medycznego w Katowicach (Department of General Surgery, \\ Vascular Surgery, Angiology and Phlebology, Medical University of Silesia, Katowice)
}

\section{Streszczenie}

Wstęp. Leczenie hormonalne i ciąża zalicza się do istotnych czynników ryzyka wystąpienia i progresji przewlekłej choroby żylnej (PChŻ). Powszechność stosowania zarówno hormonalnej terapii zastępczej, jak i doustnej antykoncepcji hormonalnej sprawia, że leczenie hormonalne stanowi jeden z częściej identyfikowanych czynników potencjalnie sprzyjających rozwojowi PChż w populacji. W dotychczas przeprowadzonych badaniach dotyczących wpływu doustnej antykoncepcji hormonalnej na układ żylny szczególne miejsce zajmuje wpływ tego typu leczenia na wystąpienie zakrzepicy żył głębokich. Równocześnie niezwykle ograniczona liczba prac dotyczy analizy bezpośredniego wpływu stosowania doustnej antykoncepcji hormonalnej na występowanie zarówno podmiotowych, jak i przedmiotowych objawów PChż w populacji pacjentek stosujących tego typu terapię. W niniejszej pracy poddano ocenie występowanie objawów PChŻ u młodych kobiet stosujących doustną antykoncepcję hormonalną, porównując uzyskane wyniki z wynikami otrzymanymi w grupie kontrolnej obejmującej pacjentki o podobnej charakterystyce, niestosujące leczenia hormonalnego.

Materiał i metoda. Badanie przeprowadzono w populacji 332 kobiet, studentek Śląskiego Uniwersytetu Medycznego w Katowicach, w wieku 20-25 lat, spośród których 201 kobiet (60,5\%) stosowało doustną antykoncepcję hormonalną. Mediana wieku badanej populacji wyniosła 22 lata, mediana czasu stosowania doustnej antykoncepcji hormonalnej - 18 miesięcy (zakres od 5 tygodni do 4 lat i 6 miesięcy). U wszystkich badanych dokonano oceny występowania objawów przedmiotowych PChŻ w oparciu o klasyfikację CEAP, jak również występowania i nasilenia objawów podmiotowych tej choroby. Wyniki uzyskane w grupie pacjentek stosujących antykoncepcję hormonalną porównano z wynikami otrzymanymi w populacji kobiet niestosujących leczenia hormonalnego W grupie kobiet stosujących doustną antykoncepcję hormonalną ocenie poddano zależność pomiędzy występowaniem objawów przedmiotowych i podmiotowych PChŻ a czasem stosowania antykoncepcji hormonalnej.

Wyniki. W obu grupach stwierdzono podobną częstość występowania zarówno podmiotowych, jak i przedmiotowych objawów PChŻ. Częstość występowania jakichkolwiek objawów przedmiotowych ocenianych zgodnie z klasą C w klasyfikacji CEAP wyniosła 36,46\% w grupie antykoncepcji hormonalnej oraz $39,59 \%$ w grupie pacjentek niestosujących tego rodzaju leczenia $(p>0,05)$. W obu grupach najczęstszą manifestacją PChŻ była obecność zmian o charakterze $\mathrm{C} 1$ pod postacią telangiektazji i żył retikularnych. Występowanie objawów podmiotowych PChŻ stwierdzono u 73,44\% pacjentek przyjmujących doustne 
leki antykoncepcyjne i u 66,41\% pacjentek niestosujących leczenia hormonalnego ( $p>0,05)$. W analizie statystycznej nie stwierdzono zależności pomiędzy czasem trwania terapii a występowaniem bólu, uczucia ciężkości kończyn oraz świądu i kurczów nocnych w grupie pacjentek stosujących leczenie hormonalne. Uwzględniając czas stosowania doustnej antykoncepcji hormonalnej, nie stwierdzono jego wpływu na występowanie żylaków i obrzęków kończyn w badanej populacji. Zaobserwowano słabą, niemniej istotną statystycznie korelację pomiędzy występowaniem zmian o charakterze telangiektazji (C1) a czasem trwania leczenia hormonalnego (współczynnik r korelacji Spearmana 0,204; $p=0,004$ ).

Wnioski. W badanej populacji młodych kobiet (20-25 lat) stosowanie doustnej antykoncepcji hormonalnej nie wpływa na wzrost częstości powszechnie występujących także w tej grupie wiekowej objawów podmiotowych PChŻ. Udokumentowany, ograniczony wpływ doustnej antykoncepcji hormonalnej na występowanie jedynie niektórych objawów przedmiotowych PChŻ wymaga potwierdzenia w dalszych badaniach. Konieczne są również dalsze badania prospektywne odnoszące się do wpływu czasu stosowania doustnej antykoncepcji hormonalnej oraz wpływu rodzaju przyjmowanych leków na wystąpienie i progresję PChŻ, w tym badania odnoszące się do innych grup wiekowych.

Słowa kluczowe: przewlekła choroba żylna (PChż), antykoncepcja hormonalna, symptomatologia, epidemiologia

Chirurgia Polska 2020, 22, 1-2, 20-28

\section{Abstract}

Introduction. Hormonal treatment and pregnancy are important risk factors for the occurrence and progression of chronic vein diseases (CVD). The widespread use of both hormone replacement therapy and oral hormone contraception $(\mathrm{OHC})$ places hormonal treatment among one of the most frequently identified factors potentially contributing to the appearance of symptoms of CVD in the population. In the studies conducted so far on the influence of OCP on the venous system, the effect of oral hormonal therapy on the occurrence of deep vein thrombosis is of particular importance. At the same time, a limited number of studies analyse the direct impact of $\mathrm{OHC}$ use on the occurrence of both symptoms and signs of CVD in the population of patients using this type of therapy. The study assessed the occurrence of symptoms of chronic venous diseases in young women using oral hormonal contraception by comparing the obtained results with the control group of patients with similar characteristics, not using hormonal treatment. Material and method. The study was conducted on a population of 332 women, students at the Medical University of Silesia in Katowice, aged 20-25, including 201 women $(60.5 \%)$ using oral hormonal contraception. The median age of the study population was 22 years, the median duration of oral hormonal contraceptive use was 18 months, ranging from 5 weeks to 4 years and 6 months. All patients were assessed for the presence of signs of CVD based on the CEAP classification, as well as for the occurrence and severity of symptoms of this disease. The results obtained in the group of patients using hormonal contraception were compared with the population of women not using hormone therapy.

Results. The incidence of signs and symptoms of the chronic venous disease was similar in both groups. The incidence of any symptoms assessed according to CEAP class $C$ was $36.46 \%$ in the group of hormonal contraceptives and $39.59 \%$ in the group of patients without this type of treatment ( $p>0.05)$. In both groups, the most common manifestation of chronic venous disease was the presence of $\mathrm{C} 1$ lesions in the form of telangiectasia and reticular veins. The presence of symptoms of CVD was found in $73.44 \%$ of the population of patients taking oral contraceptives and in $66.41 \%$ of patients not using hormonal therapy ( $p>0.05$ ). In the statistical analysis, no correlation was found between the duration of therapy and the occurrence of pain, the feeling of heaviness in the limbs as well as itching and night cramps in this group of patients using hormonal therapy. Considering the time factor of using oral hormonal contraceptives, there was no effect of the duration of oral hormonal contraceptive use on the occurrence of varicose veins and swelling of the limbs in the studied population. At the same time, a weak but statistically significant correlation was observed between the occurrence of telangiectasias (C1) and the duration of hormonal treatment (Spearman's $r$ correlation coefficient 0.204; $p=0.004$ ).

Conclusions. In the studied population of young women (20-25 years), the use of oral hormonal contraception did not increase the frequency of the occurrence of the CVD symptoms, commonly present in this age group. The documented, limited influence of $\mathrm{OHC}$ on the occurrence of only some of the signs of CVD requires confirmation in further studies. Further prospective studies are also required regarding the effect of the duration of $\mathrm{OHC}$ use and the effect of the type of oral contraception drugs on the occurrence and progression of CVD, including the studies relating to other age groups.

Key words: chronic venous diseases, hormonal contraception, symptomatology, epidemiology

Chirurgia Polska 2020, 22, 1-2, 20-28 


\section{Wstęp}

Leczenie hormonalne to jeden z częściej wskazywanych w literaturze czynników ryzyka rozwoju i progresji przewlekłej choroby żylnej (PChŻ) [1]. Częstość występowania PChŻ w populacji krajów zachodnich umiejscawia tę grupę schorzeń wśród najczęstszych chorób układu naczyniowego. Według badań epidemiologicznych żylaki kończyn dolnych obecne są u 25-33\% kobiet i u 10-40\% dorosłych mężczyzn [1].

Jak wskazuje Jawień, objawy podmiotowe i/lub przedmiotowe PChŻ występują u 37\% dorosłych mężczyzn i $45 \%$ dorosłych kobiet w Polsce, zgłaszających się na wizytę lekarską w lecznictwie ambulatoryjnym [2].

Szeroki zakres objawów przedmiotowych oraz różnorodność i zróżnicowane nasilenie objawów podmiotowych związanych z PChŻ przekładają się na często zróżnicowany obraz kliniczny u poszczególnych chorych. Stwierdzane zmiany mogą stanowić dla pacjenta jedynie problem estetyczny (np. obecność pajączków żylnych czy poszerzonych żył retikularnych) lub też być przyczyną istotnych klinicznie dolegliwości (np. występowanie obrzęków, zmian troficznych bądź owrzodzeń żylnych goleni) [1, 3].

Niezwykle istotne z punktu widzenia jakości życia pacjenta jest również występowanie subiektywnie odczuwanych przez chorego objawów podmiotowych, w tym bólu kończyn, uczucia ciężkości, uczucia obrzęku, świądu czy też kurczów nocnych [1]. Dolegliwości te mogą występować z różnym nasileniem oraz ulegać zmianie w zależności od pory dnia i trybu życia chorego (nasilenie zwykle w godzinach popołudniowych i wieczornych, $\mathrm{w}$ trakcie długotrwałego przebywania w pozycji stojącej lub siedzącej). W tym miejscu należy podkreślić fakt, że objawy podmiotowe nie zawsze korelują jednoznacznie z występowaniem objawów przedmiotowych. Dobrym przykładem jest tutaj grupa pacjentów C0s [wg klasyfikacji CEAP - objawy kliniczne (C, clinical), etiologia (E, etiological), lokalizacja anatomiczna (A, anatomical) i przyczyny patofizjologiczne ( $P$, pathophysiological)], w przypadku której mimo braku widocznych znamion choroby żył w badaniu przedmiotowym podawane przez chorego dolegliwości sugerują obecność PChŻ (np. uczucie ciężkości, bóle kończyn, uczucie obrzęku nasilające się w ciągu dnia) [3]. Według opublikowanych wyników badania Vein Consult Program pacjenci klasyfikowani jako COs stanowią do $20 \%$ całej populacji chorych z PChŻ [4].

Ważną klinicznie informacją jest też fakt coraz częstszego występowania PChŻ wraz z coraz bardziej zaawansowanym wiekiem. Równocześnie należy jednak podkreślić, że schorzenie to relatywnie często dotyczy również osób młodych, w tym pacjentów eksponowanych na potencjalne czynniki ryzyka wystąpienia i progresji PChŻ. Zgodnie z doniesieniami z piśmiennictwa poza obciążeniami genetycznymi, otyłością i trybem życia (np. mała ilość ruchu, pozycja siedząca przez większość dnia) znaczenie w tym zakresie mają także inne czynniki, w tym leczenie hormonalne (antykoncepcja, hormonalna terapia zastępcza, stosowanie hormonów steroidowych z in- nych wskazań) bądź ciąża [1, 2]. Obecność receptorów hormonalnych (w tym dla estrogenów w ścianach żył), większa częstość występowania objawów podmiotowych i przedmiotowych PChŻ w czasie ciąży, zwiększona częstość występowania zarówno pajączków, jak i żylaków kończyn oraz objawów nadciśnienia w obrębie żył miednicy u pacjentek, które mają w wywiadzie przebytą ciążę, sugerują związek pomiędzy wpływem hormonów płciowych a patogenezą zmian towarzyszących PChŻ. Jedną z częstszych w obecnych czasach przyczyn klinicznych leczenia hormonalnego jest antykoncepcja hormonalna. Jej wpływ na układ żylny poddano wielu badaniom w aspekcie ryzyka wystąpienia zakrzepicy żył głębokich w populacji kobiet stosujących tę metodę $[5,6]$.

Mimo że leczenie hormonalne ( $w$ tym antykoncepcja hormonalna) znajduje się według wielu opracowań na liście czynników ryzyka rozwoju PChŻ, liczba przeprowadzonych in vivo badań dotyczących zagadnienia bezpośredniego wpływu antykoncepcji hormonalnej na obecność i nasilenie objawów podmiotowych PChŻ pozostaje ograniczona [1]. Brak jest także nadal wysokiej jakości długoterminowych obserwacji odnoszących się do wpływu antykoncepcji na progresję PChŻ i rozwój żylaków kończyn. W badaniu przedstawionym w niniejszej publikacji autorzy podjęli próbę oceny wpływu doustnej antykoncepcji hormonalnej (DAH) na występowanie objawów podmiotowych PChŻ. Badanie uzupełniono o analizę występowania objawów przedmiotowych PChŻ u młodych kobiet stosujących ten rodzaj leczenia hormonalnego.

\section{Materiał i metoda}

Badanie obejmowało populację 332 kobiet, studentek Śląskiego Uniwersytetu Medycznego w Katowicach, w wieku 20-25 lat, spośród których 201 (60,5\%) stosowało DAH. Mediana wieku badanej populacji wyniosła 22 lata. Mediana czasu stosowania DAH wyniosła 18 miesięcy (zakres od 5 tygodni do 4 lat i 6 miesięcy), przy czym najwięcej $(23,9 \%)$ pacjentek wskazywało na okres przyjmowania DAH wynoszący 1-2 lat. Badane grupy (kobiety stosujące DAH oraz grupa kontrolna - kobiety nieprzyjmujące doustnej antykoncepcji hormonalnej) nie różniły się pod względem wieku, średniego wskaźnika masy ciała (BMI, body mass index), jak również występowania nadwagi i otyłości (tab. I).

Tabela I. Porównanie grup kobiet stosujących i niestosujących doustnej antykoncepcji hormonalnej

\begin{tabular}{|l|l|l|l|}
\hline Cecha & $\begin{array}{l}\text { Kobiety niestosu- } \\
\text { jące DAH } \\
\mathbf{n = 1 3 1}\end{array}$ & $\begin{array}{l}\text { Kobiety stosujące } \\
\text { DAH } \\
\mathbf{n = 2 0 1}\end{array}$ & $\begin{array}{l}\text { Wartość staty- } \\
\text { styki }\end{array}$ \\
\hline $\begin{array}{l}\text { Mediana wieku } \\
\text { (lata) }\end{array}$ & 22,00 & 22,00 & $\mathrm{p}>0,05$ \\
\hline BMl (średnia \pm SD) & $21,12( \pm 3,0)$ & $21,23( \pm 2,9)$ & $\mathrm{p}>0,05$ \\
\hline Nadwaga & $8(6,1 \%)$ & $18(9,4 \%)$ & $\mathrm{p}>0,05$ \\
\hline Otyłość & $4(3,1 \%)$ & $3(1,6 \%)$ & $\mathrm{p}>0,05$ \\
\hline
\end{tabular}

SD (standard deviation) — odchylenie standardowe 


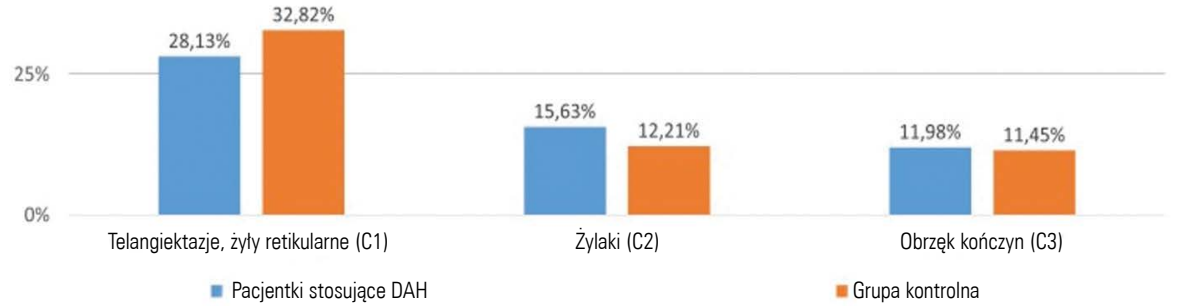

Rycina 1. Występowanie objawów przedmiotowych PChż w grupie stosującej doustną antykoncepcję hormonalną (DAH) oraz u pacjentek z grupy kontrolnej (bez antykoncepcji hormonalnej) - różnice w zakresie występowania zmian C1-C3 pomiędzy grupami nieistotne statystycznie $(p>0,05)$

Z badania wykluczono pacjentki stosujące leczenie hormonalne ze wskazań innych niż antykoncepcja, jak również kobiety w ciąży i po przebytej ciąży. Do badania nie kwalifikowano też pacjentek z wywiadem w kierunku zakrzepicy żył głębokich i powierzchownych. U wszystkich badanych dokonano oceny występowania objawów przedmiotowych PChż na podstawie klasyfikacji CEAP. Przy wykorzystaniu specjalnie opracowanego kwestionariusza oceniono występowanie i nasilenie objawów podmiotowych PChŻ, w tym: bólu kończyn dolnych, uczucia ciężkości, świądu skóry i kurczów nocnych. Stopień nasilenia poszczególnych objawów podmiotowych oceniano w wizualnej skali analogowej (VAS, visual analogue scale), w zakresie 0-7 punktów, gdzie 0 oznaczało brak dolegliwości o zdefiniowanym charakterze, a 7 - ich maksymalne nasilenie. Wyniki uzyskane $w$ grupie kobiet stosujących DAH porównano z wynikami otrzymanymi w populacji kobiet niestosujących leczenia hormonalnego i poddano analizie statystycznej przy wykorzystaniu programu STATISTICA. W analizie dokonano porównania występowania objawów podmiotowych i przedmiotowych PChŻ pomiędzy populacjami pacjentek stosujących i niestosujących DAH. W grupie kobiet stosujących DAH ocenie poddano zależność pomiędzy występowaniem objawów przedmiotowych i podmiotowych PChŻ a czasem stosowania antykoncepcji hormonalnej.

\section{Wyniki}

W obu grupach kobiet - zarówno stosujących, jak i niestosujących DAH —stwierdzono podobną częstość występowania objawów podmiotowych i przedmiotowych PChŻ. Częstość występowania jakichkolwiek objawów przedmiotowych ocenianych zgodnie z klasą $C$ w klasyfikacji CEAP wyniosła $36,46 \%$ w grupie DAH oraz $39,59 \%$ w grupie pacjentek niestosujących tego rodzaju leczenia; różnica ta nie była istotna statystycznie $(p>0,05)$. W obu grupach najczęstszą manifestacją PChŻ była obecność zmian o charakterze $\mathrm{C} 1$ pod postacią telangiektazji i żył retikularnych. Szczegółowe dane dotyczące występowania poszczególnych objawów przedmiotowych przedstawiono na rycinie 1 .

Występowanie objawów podmiotowych PChż (jakiegokolwiek z badanych objawów: bóle kończyn, uczucie ciężkości, świąd skóry, kurcze nocne) stwierdzono u $73,44 \%$ pacjentek przyjmujących DAH oraz u $66,41 \%$ pacjentek niestosujących DAH (różnica nieistotna statystycznie). Szczegółowe informacje co do częstości występowania poszczególnych objawów przedstawiono na rycinie 2 . U 36,98\% kobiet stosujących i u $26,28 \%$ niestosujących DAH stwierdzano występowanie jakiegokolwiek spośród ocenianych objawów podmiotowych bez obecności objawów przedmiotowych (C1-C3). Tę grupę pacjentek sklasyfikowano jako C0s według klasyfikacji CEAP.

Istotnej statystycznie różnicy pomiędzy grupami nie stwierdzono również w ocenie ilościowej stopnia nasilenia poszczególnych dolegliwości ocenianego w VAS. W 7-stopniowej skali, gdzie 0 oznaczało brak dolegliwości, a 7 - ich maksymalne nasilenie, w grupie kobiet zgłaszającej występowanie bólu kończyn średnia wartość w skali VAS dla bólu wyniosła 2,59 $\pm 1,18$ dla pacjentek stosujących DAH oraz 2,83 $\pm 1,31$ dla pacjentek bez leczenia hormonalnego $(p>0,05)$. Odpowiednie wartości dla zgłaszanego uczucia ciężkości kończyn wyniosły wśród pacjentek podających występowanie tego objawu $3,52 \pm 0,77$ oraz $3,56 \pm 0,91(p>0,05)$. Znamiennej statystycznie różnicy pomiędzy nasileniem objawów w wyróżnionych grupach nie stwierdzono także dla uczucia świądu oraz kurczów nocnych (ocena nasilenia zgłaszanych dolegliwości u chorych objawowych w skali VAS). 

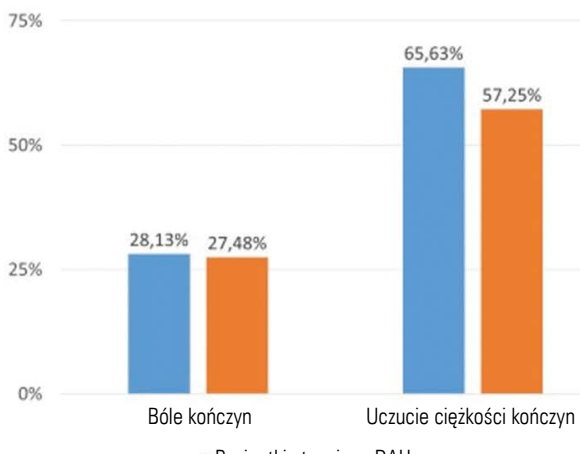

-Pacjentki stosujące DAH

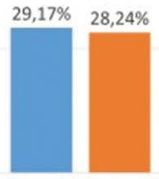

Świąd skóry

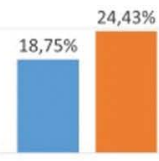

Kurcze nocne

= Grupa kontrolna

Rycina 2. Występowanie objawów podmiotowych PChŻ w grupie stosującej doustną antykoncepcję hormonalną (DAH) oraz u pacjentek z grupy kontrolnej (bez antykoncepcji hormonalnej) — różnice w zakresie występowania poszczególnych objawów pomiędzy grupami nieistotne statystycznie $(p>0,05)$

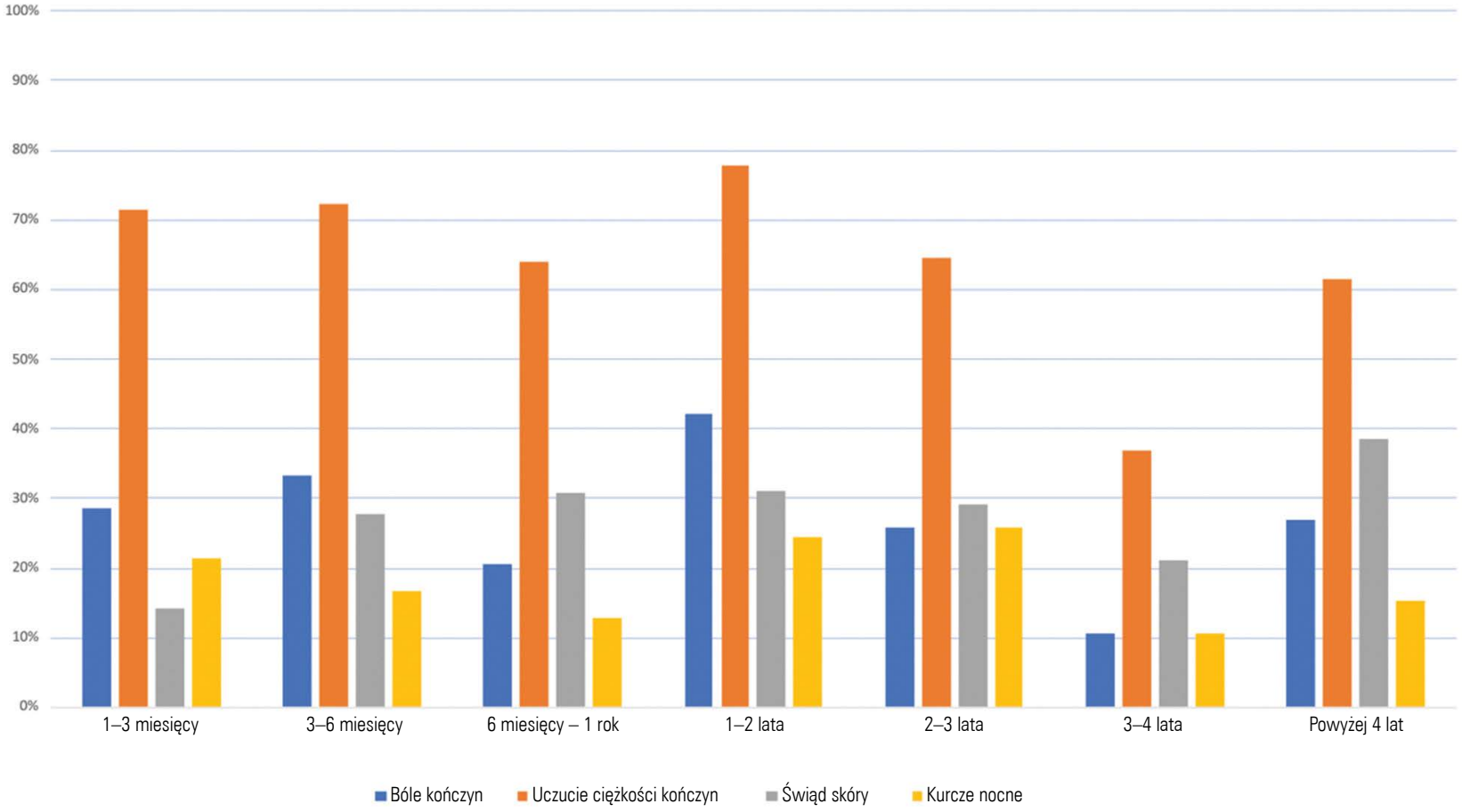

Rycina 3. Występowanie poszczególnych objawów podmiotowych w zależności od czasu stosowania doustnej antykoncepcji hormonalnej. W analizie statystycznej brak korelacji pomiędzy występowaniem bólów kończyn, uczucia ciężkości, świądu skóry i kurczów kończyn a czasem trwania terapii hormonalnej — brak istotnych statystycznie zmian w zakresie występowania objawów podmiotowych w funkcji czasu

W dalszym etapie analizy oceniano zależność pomiędzy czasem trwania leczenia hormonalnego (stosowania DAH) a występowaniem podmiotowych i przedmiotowych objawów PChŻ. Na rycinie 3 przedstawiono wykres zależności pomiędzy czasem stosowania DAH a występowaniem podawanych przez pacjentki objawów podmiotowych w grupie stosującej antykoncepcję. W analizie statystycznej nie stwierdzono zależności pomiędzy czasem trwania terapii a występowaniem bólu, uczucia ciężkości kończyn oraz świądu i kurczów nocnych w tej grupie badanych.

Analizując występowanie odnotowanych objawów przedmiotowych (obecność jakiegokolwiek objawu przedmiotowego) w zależności od czasu stosowania DAH, nie zaobserwowano istotnego statystycznie związku pomiędzy czasem przyjmowania DAH a obecnością zmian 


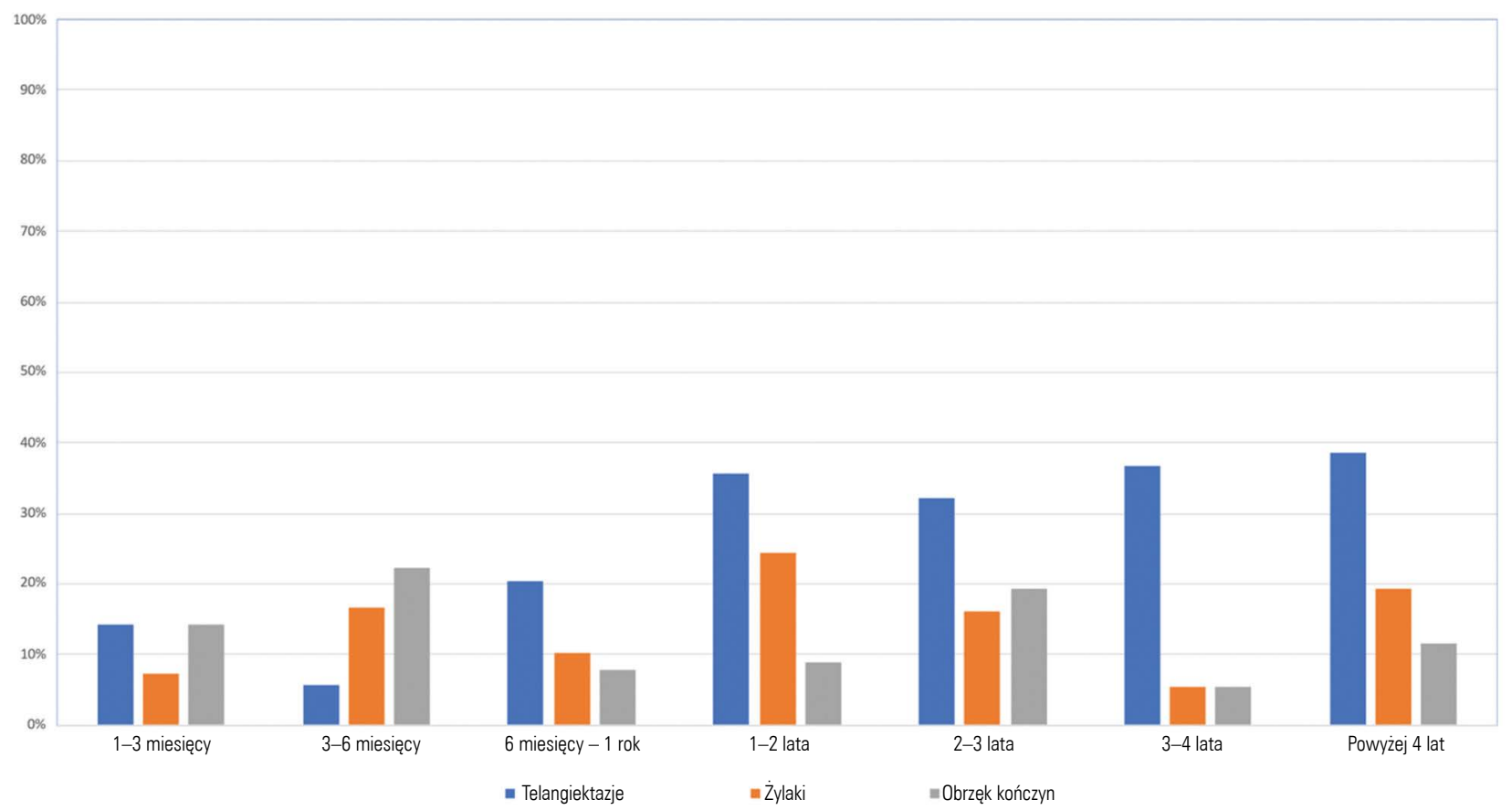

Rycina 4. Występowanie objawów przedmiotowych PChŻ w funkcji czasu u pacjentek stosujących DAH. Współczynnik korelacji Spearmana $r=0,204$ dla występowania telangiektazji w funkcji czasu $(p=0,004)$; brak korelacji dla pozostałych objawów (żylaki, obrzęki)

w badaniu przedmiotowym (telangiektazje, żylaki lub obrzęki bądź współistnienie objawów przedmiotowych). W dalszej analizie ocenie poddano wpływ czasu stosowania DAH na obecność poszczególnych, indywidualnych objawów przedmiotowych, próbując odpowiedzieć na pytanie, czy czas trwania leczenia hormonalnego ma wpływ na wystąpienie telangiektazji, żylaków lub obrzęków jako pojedynczego objawu (ryc. 4). W analizie statystycznej nie stwierdzono wpływu czasu stosowania DAH na występowanie żylaków i obrzęków kończyn (w okresie przyjmowania leków od 5 tygodni do 4 lat i 6 miesięcy). Równocześnie zaobserwowano słabą, niemniej istotną statystycznie korelację pomiędzy występowaniem zmian o charakterze telangiektazji a czasem trwania leczenia hormonalnego (współczynnik r korelacji Spearmana 0,204; $p=0,004)$.

\section{Dyskusja}

Przewlekła choroba żylna jako jedna z najbardziej rozpowszechnionych chorób układu naczyniowego może dotyczyć nie tylko pacjentów w zawansowanym wieku, ale również osób młodych. Fakt częstszego występowania choroby wraz ze starszym wiekiem w badanej populacji nie wyklucza obecności objawów zarówno podmiotowych, jak i przedmiotowych PChŻ u młodszych pacjentek. W badanej populacji młodych kobiet, studentek Śląskiego Uniwersytetu Medycznego, częstość występowania jakichkolwiek objawów przedmiotowych PChŻ oszacowano w zależności od badanej grupy na $36,46 \%$ i 39,59\%. Wśród stwierdzanych odchyleń od stanu prawidłowego w badanej populacji potwierdzono obecność zmian w za- kresie C1-C3 według klasyfikacji CEAP lodpowiednio: telangiektazje/żyły retikularne, żylaki kończyn, obrzęki kończyn) przy największym rozpowszechnieniu zmian o charakterze C1. W tym miejscu należy podkreślić też duży odsetek pacjentek objawowych w obu badanych grupach, zarówno stosujących, jak i niestosujących DAH — odpowiednio $73,44 \%$ i $66,41 \%$. Obserwacje te potwierdzają liczne badania dotyczące częstości występowania objawów podmiotowych PChŻ w populacji krajów zachodnich. W badaniu Bonn Vein Study częstość występowania objawów PChŻ, w tym uczucia ciężkości, bólu, a także obrzęku kończyn, oszacowano w populacji osób dorosłych na $62 \%$ u kobiet i $49 \%$ u mężczyzn [7]. W badaniu przeprowadzonym w Luksemburgu i Belgii objawowi chorzy z PChŻ stanowili aż $61 \%$ badanej populacji [8]. W badaniu wykonanym w Polsce na zlecenie Polskiego Towarzystwa Flebologicznego, obejmującym reprezentatywną grupę dorosłych Polek i Polaków, uczucie ciężkości kończyn dolnych zgłaszało $62 \%$ badanych, a bóle kończyn związane z długim staniem i siedzeniem podawało $37 \%$ ankietowanych [9].

Wpływ leczenia hormonalnego, a w szczególności wpływ stosowania hormonów płciowych, na układ żylny był tematem wielu badań dotyczących zarówno ryzyka żylnej choroby zakrzepowo-zatorowej, jak i możliwości rozwoju i progresji PChŻ [10]. Zgodnie z dostępnym piśmiennictwem stosowanie leczenia hormonalnego opartego na wykorzystaniu hormonów steroidowych stanowi istotny czynnik ryzyka wystąpienia zakrzepicy żył głębokich i żylnej choroby zakrzepowo-zatorowej [11].

Częstsze występowanie żylaków kończyn, w tym niewydolności żył miednicy, jak również wielu innych postaci 
zaawansowania PChŻ (w tym zmian o charakterze C1) u kobiet, zmiany w układzie żylnym związane z obecną ciążą oraz ciążami przebytymi w przeszłości wskazują na istotną rolę stanu hormonalnego pacjentki w kontroli homeostazy układu żylnego. Obecność receptorów estrogenowych i progesteronowych w układzie żylnym wykryto w licznych dotychczas przeprowadzonych badaniach odnoszących się zarówno do zdrowych naczyń żylnych, jak i do naczyń zmienionych żylakowato [12-15].

Mashiah i wsp. sugerują większą ekspresję receptorów estrogenowych w ścianach odcinków żył zmienionych żylakowato niż w naczyniach prawidłowych [12]. Perrot-Applanat i wsp. potwierdzili występowanie receptorów progesteronowych w większości bioptatów żyły odpiszczelowej pobranych w trakcie jej strippingu, sugerując równocześnie wpływ progesteronu na powstawanie żylaków kończyn [16].

Zwiększoną ekspresję genów dla trzech rodzajów receptorów estrogenowych w ścianach naczyń żylnych udokumentowali w swoim badaniu Serra i wsp. [17]. W porównaniu z wycinkami zdrowych żył (grupa kontrolna), w grupie pacjentów z żylakami obserwowano zwiększoną ekspresję receptorów estrogenowych alfa, beta oraz receptora sprzężonego z białkiem G (GPER, G protein-coupled ER) w ścianach żył u chorych z PChŻ [17].

W dostępnej literaturze nadal trwa dyskusja na temat dróg oddziaływania hormonów płciowych na homeostazę układu żylnego oraz stan napięcia (tonusu) naczyń żylnych. Dotychczasowe obserwacje sugerują relaksacyjny wpływ estrogenów na komórki mięśni gładkich oraz hamujące działanie progesteronu na skurcz naczyń żylnych [18].

W badaniu przeprowadzonym w modelu zwierzęcym Raffetto i wsp. udowodnili związek pomiędzy obecnością specyficznych receptorów estrogenowych a relaksacją ściany naczynia żylnego [19]. Jilma i wsp. sugerują, że powodowane działaniem estradiolu zmniejszenie napięcia ściany żyły może wynikać z wpływu tego hormonu na odpowiedź receptorów alfa-adrenergicznych w komórkach mięśni gładkich ścian żył powierzchownych [20]. O wazorelaksacyjnym wpływie estradiolu na napięcie ściany naczynia piszą również inni autorzy [21, 22].

Babaei i Azarmi sugerują, że hamujący wpływ 17-beta estradiolu na skurcz naczyń żylnych wiąże się z wpływem tego hormonu zarówno na drogi aktywacji skurczu mięśni gładkich zależne od jonów wapnia, jak i na mechanizmy od nich niezależne [22].

Wiele innych prac poza wymienionymi sugeruje jednak także znacznie bardziej trwałe oddziaływanie hormonów płciowych na strukturę naczyń żylnych, skutkujące rozwojem i progresją zmian degeneracyjnych w ścianie naczynia. Przyczyną tego zjawiska jest potencjalny wpływ estrogenów na zmianę objętości, jak również fenotypu komórek mięśni gładkich, powodujący zaburzenia struktury ściany naczynia żylnego oraz rozluźnienie i dezorganizację sieci włókien kolagenowych. Estradiol hamuje proliferację komórek mięśni gładkich i stymuluje sekrecję protein macierzy międzykomórkowej. Dodatkowym istotnym efektem działania estradiolu wydaje się zwiększenie produkcji tlenku azotu i jego biodostępności [18]. Knaapen i wsp. sugerują związek pomiędzy ekspresją receptorów estrogenowych beta a hipertrofią komórek mięśni gładkich powodującą dezorganizację struktury ściany naczynia u osób z żylakami kończyn [23, 24].

W opublikowanej w 2020 roku pracy Zhao i wsp. wskazują też na potencjalny wpływ estrogenów za pośrednictwem receptorów estrogenowych na ekspresję mających kluczowe znaczenie dla zmian degeneracyjnych w ścianie żyły metaloproteinaz MMP2 i MMP9 [25]. Potencjalny wpływ hormonów płciowych na występowanie żylaków kończyn sugerowany jest także w populacji mężczyzn [26]. Pobierając krew z żył kończyny górnej oraz z niewydolnej żyły odpiszczelowej, Kendler i wsp. stwierdzili istotnie wyższe stężenia osoczowego testosteronu i estradiolu w segmentach naczyń z niewydolnością żylną [26].

Obecność relaksacji ściany naczyń i zmiany tonusu żylnego związane z funkcją hormonalną potwierdzono nie tylko w badaniach odnoszących się do nauk podstawowych, ale również w badaniach in vivo. Przykładem tego rodzaju sytuacji klinicznej jest okres ciąży, w czasie której obserwuje się liczne zmiany w obrębie układu żylnego, wynikające nie tylko ze zwiększenia objętości płynów ustrojowych czy wzrostu macicy, ale także ze zmian w gospodarce hormonalnej [27].

Obserwacje kliniczne potwierdzają też występowanie zmian w układzie żylnym w trakcie cyklu miesięcznego. Oceniając średnice ścian żył powierzchownych oraz analizując czas zamknięcia zastawek żylnych w poszczególnych okresach cyklu miesięcznego, Asbeutah i wsp. odnotowali istotne różnice $\mathrm{w}$ zakresie analizowanych parametrów, zależne od fazy cyklu związanej z aktualną funkcją hormonalną badanych kobiet [28].

W przedstawionych wcześniej wynikach niniejszej pracy nie udokumentowano istotnych różnic pomiędzy grupą młodych kobiet stosujących DAH i grupą kobiet, które nie przyjmowały tego rodzaju preparatów, w zakresie występowania zarówno objawów przedmiotowych, jak i przedmiotowych PChŻ. W obu grupach z podobną częstością stwierdzano zmiany o charakterze C1, C2 i C3. W tym miejscu należy jednak podkreślić relatywnie krótki średni czas trwania terapii hormonalnej (mediana 18 miesięcy) w badanej populacji oraz młody wiek populacji (20-25 lat). Uwzględniając czynnik czasu stosowania DAH, zgodnie z wynikami przeprowadzonej analizy nie stwierdzono wpływu czasu ekspozycji badanych kobiet na doustne leki antykoncepcyjne na występowanie zarówno żylaków, jak i obrzęków kończyn. Stwierdzono jedynie słabą korelację pomiędzy występowaniem pajączków żylnych a czasem trwania DAH. Obserwacją wymagającą niewątpliwie dalszych badań był brak istotnej statystycznie różnicy pomiędzy obiema grupami (młodych kobiet stosujących DAH oraz niestosujących tego rodzaju leczenia) w zakresie występowania bólów kończyn, uczucia ciężkości, świądu i kurczów nocnych, jak również nasilenia tych dolegliwości $w$ badanej populacji. W dostępnym piśmiennictwie można znaleźć niespójne i często niejednoznaczne dane dotyczące wpływu DAH na występowanie objawów podmiotowych i przedmiotowych PChŻ. Podkreślenia 
wymaga też ograniczona dostępność długoterminowych obserwacji klinicznych w tym zakresie. Mimo że leczenie hormonalne, a także ciąża są powszechnie znanymi czynnikami ryzyka rozwoju i progresji PChŻ, dostępna literatura nadal zawiera niewielką liczbę prac dotyczących długoterminowej prospektywnej obserwacji kobiet stosujących DAH pod kątem rozwoju PChŻ.

Jukkola i wsp. w badaniu epidemiologicznym obejmującym grupę 3590 pacjentek w wieku 40-60 lat analizowali wpływ przebytych ciąż, stosowania DAH oraz hormonalnej terapii zastępczej na występowanie żylaków kończyn w czasie 5-letniej obserwacji. W analizie statystycznej niezależnym czynnikiem ryzyka wystąpienia żylaków kończyn okazało się przebycie co najmniej trzech ciąż zakończonych porodem, równocześnie nie stwierdzono jednak wpływu stosowania DAH na zwiększoną częstość występowania żylaków [29]. Kostas i wsp. w 5-letniej obserwacji dotyczącej pacjentek poddanych leczeniu żylaków kończyn i stosujących terapię estrogenową, oceniając występowanie nowych źródeł refluksu w żyłach kończyn dolnych, nie stwierdzili wpływu tego rodzaju leczenia hormonalnego na pojawianie się nowych miejsc niewydolności żylnej identyfikowanej w badaniu ultrasonografii (USG) metodą Dopplera [30].

W przeciwieństwie do wyników tych doniesień, związek leczenia hormonalnego, w tym antykoncepcji hormonalnej [DAH], z występowaniem pajączków żylnych i żylaków kończyn sugerują Sadick, Ciardullo oraz Abou-EIWafa [31-33]. W ostatniej spośród tych prac, dotyczącej populacji żeńskiego personelu pielęgniarskiego w Egipcie, stosowanie DAH okazało się istotnym czynnikiem ryzyka występowania żylaków kończyn [33]. Analizując wyniki badania Edinburgh Vein Study, Fowkes i wsp. jako czynniki związane z obecnością refluksu w układzie żył powierzchownych zidentyfikowali przebytą ciążę oraz wcześniejsze stosowanie DAH [34].

Vin i wsp. oceniając wpływ rodzaju stosowanych leków hormonalnych na występowanie objawów podmiotowych PChŻ, poddali badaniu 2295 kobiet w wieku 21-40 lat z rozpoznaną PChŻ przyjmujących tego rodzaju preparaty [35]. W badanej populacji obecność objawów podmiotowych PChŻ stwierdzano już w okresie 1-3 lat przed włączeniem do badania, a pacjentki stosowały leki zawierające zróżnicowane dawki zarówno estrogenów, jak i progesteronu, w tym preparaty ze zredukowanymi dawkami estrogenów. Jak podają autorzy doniesienia, przyjmowanie standardowych dawek hormonów w DAH wiązało się z większą intensywnością uczucia ciężkości oraz bólu niż stosowanie dawek zredukowanych. Równocześnie nie zauważono wpływu dawek hormonów na nasilenie takich dolegliwości jak występowanie kurczów oraz obrzęku kończyn [35].

W badaniu będącym przedmiotem niniejszej analizy nie zaobserwowano różnic w zakresie występowania ocenianych objawów podmiotowych pomiędzy grupą przyjmującą DAH a pacjentkami, które nie stosowały tego rodzaju leczenia. Z uwagi na ograniczoną wielkość grupy oraz zróżnicowane sposoby leczenia hormonalnego
W analizie nie uwzględniono jednak potencjalnych różnic w zakresie wpływu różnych dawek poszczególnych hormonów na wyniki obserwacji. Autorzy niniejszej pracy zdają sobie sprawę także z innych ograniczeń przeprowadzonego badania, wśród których należy wymienić ograniczoną liczebność badanej populacji oraz stosunkowo krótki maksymalny czas trwania leczenia hormonalnego (4 lata i 6 miesięcy). Istotnym ograniczeniem wydaje się też brak wykonania badania USG dupleks metodą Dopplera w całej badanej grupie - u pacjentek zarówno leczonych, jak i nieleczonych hormonalnie. Niewątpliwym ograniczeniem jest także wiek badanej populacji, nieprzekraczający 25 lat.

\section{Wnioski}

W badanej populacji młodych kobiet (20-25 lat) stosowanie DAH nie wpływa na wzrost częstości powszechnie występujących również w tej grupie wiekowej objawów podmiotowych PChŻ. Udokumentowany, ograniczony wpływ DAH na występowanie jedynie niektórych objawów przedmiotowych PChŻ wymaga potwierdzenia w dalszych badaniach. Konieczne są też dalsze prospektywne badania dotyczące wpływu czasu stosowania DAH, a także wpływu rodzaju przyjmowanych leków na rozwój i progresję PChŻ, w tym badania odnoszące się do innych grup wiekowych.

\section{Piśmiennictwo}

1. Nicolaides A, Kakkos S, Baekgaard N, et al. Management of chronic venous disorders of the lower limbs. Guidelines According to Scientific Evidence. Part I. Int Angiol. 2018; 37(3): 181-254, doi: 10.23736/S0392-9590.18.03999-8, indexed in Pubmed: 29871479.

2. Jawien A. The influence of environmental factors in chronic venous insufficiency. Angiology. 2003; 54 Suppl 1: S19-S31, doi: 10.1177/0003319703054001S04, indexed in Pubmed: 12934754.

3. Lurie F, Passman M, Meisner M, et al. The 2020 update of the CEAP classification system and reporting standards. J Vasc Surg Venous Lymphat Disord. 2020; 8(3): 342-352, doi: 10.1016/j. jvsv.2019.12.075, indexed in Pubmed: 32113854.

4. Rabe E, Guex JJ, Puskas A, Scuderi A, Fernandez Quesada F, VCP Coordinators Epidemiology of chronic venous disorders in geographically diverse populations: results from the Vein Consult Program Int Angiol. 2012; 31: 105-115, indexed in Pubmed: 22466974.

5. Mohammed K, Abu Dabrh AM, Benkhadra K, et al. Oral vs Transdermal Estrogen Therapy and Vascular Events: A Systematic Review and Meta-Analysis. J Clin Endocrinol Metab. 2015; 100(11): 4012-4020, doi: 10.1210/jc.2015-2237, indexed in Pubmed: 26544651.

6. Dragoman MV, Tepper NK, Fu R, et al. A systematic review and meta-analysis of venous thrombosis risk among users of combined oral contraception. Int J Gynaecol Obstet. 2018; 141(3): 287-294, doi: 10.1002/ijgo.12455, indexed in Pubmed: 29388678.

7. Pannier-Fischer F, Bromen K, Schuldt K, et al. Bonner Venenstudie der Deutschen Gesellschaft für Phlebologie. Phlebologie. 2018; 32(01): 1-14, doi: 10.1055/s-0037-1617353.

8. Vuylsteke ME, Thomis S, Guillaume G, et al. Epidemiological study on chronic venous disease in Belgium and Luxembourg: prevalence, risk factors, and symptomatology. Eur J Vasc Endo- 
vasc Surg. 2015; 49(4): 432-439, doi: 10.1016/j.ejvs.2014.12.031, indexed in Pubmed: 25701071.

9. Urbanek T, Dorobisz A, Gabriel M, et al. Assessment of public awareness in the field of epidemiology, prevention and treatment of chronic venous diseases in Poland. Phlebological Review. 2015; 2: 45-53, doi: 10.5114/pr.2015.54035.

10. Beck W. Complications and contraindications of oral contraception. Clin Obstet Gynecol. 1981; 24(3): 893-902, doi: 10.1097/00003081198109000-00016, indexed in Pubmed: 7026110.

11. Tepper NK, Marchbanks PA, Curtis KM. Superficial venous disease and combined hormonal contraceptives: a systematic review. Contraception. 2016; 94(3): 275-279, doi: 10.1016/j.contraception.2015.03.010, indexed in Pubmed: 25835269.

12. Mashiah A. Estrogen and progesterone receptors in normal and varicose saphenous veins. Cardiovascular Surgery. 1999; 7(3): 327-331, doi: 10.1016/s0967-2109(98)00132-x.

13. Krasiński Z, Kotwicka M, Oszkinis G, et al. [Investigations on the pathogenesis of primary varicose veins]. Wiad Lek. 1997; 50(1012): 275-280, indexed in Pubmed: 9557112.

14. Smiley DA, Khalil RA. Estrogenic compounds, estrogen receptors and vascular cell signaling in the aging blood vessels. Curr Med Chem. 2009; 16(15): 1863-1887, doi: 10.2174/092986709788186093, indexed in Pubmed: 19442151.

15. Bergqvist A, Bergqvist D, Fernö M. Estrogen and progesterone receptors in vessel walls. Biochemical and immunochemical assays. Acta Obstet Gynecol Scand. 1993; 72(1): 10-16, doi: 10.3109/00016349309013341, indexed in Pubmed: 8382423.

16. Perrot-Applanat M, Cohen-Solal K, Milgrom E, et al. Progesterone receptor expression in human saphenous veins. Circulation. 1995; 92(10): 2975-2983, doi: 10.1161/01.cir.92.10.2975, indexed in Pubmed: 7586268

17. Serra R, Gallelli L, Perri $P$, et al. Estrogen Receptors and Chronic Venous Disease. Eur J Vasc Endovasc Surg. 2016; 52(1): 114-118, doi: 10.1016/j.ejvs.2016.04.020, indexed in Pubmed: 27220899.

18. Ropacka-Lesiak M, Kasperczak J, Breborowicz GH. [Risk factors for the development of venous insufficiency of the lower limbs during pregnancy--part 1]. Ginekol Pol. 2012; 83(12): 939-942, indexed in Pubmed: 23488298.

19. Raffetto JD, Qiao X, Beauregard KG, et al. Estrogen receptormediated enhancement of venous relaxation in female rat: implications in sex-related differences in varicose veins. J Vasc Surg. 2010; 51(4): 972-981, doi: 10.1016/j.jvs.2009.11.074, indexed in Pubmed: 20347696.

20. Jilma $B$, Wolzt $M$, Wagner OF, et al. In vivo study of the effect of exogenous estradiol on alpha-adrenoceptor responsiveness of human veins. J Cardiovasc Pharmacol. 1994; 23(6): 859-863, doi: 10.1097/00005344-199406000-00001, indexed in Pubmed: 7523775.

21. Jodati $A R$, Babaei $H$, Azarmi $Y$, et al. Vasorelaxant effect of $17 \alpha$-ethynylestradiol on human saphenous vein. Adv Pharm Bull. 2015; 5(1): 89-96, doi: 10.5681/apb.2015.012, indexed in Pubmed: 25789224.

22. Babaei H, Azarmi Y. 17beta-estradiol inhibits calcium-dependent and -independent contractions in isolated human saphenous vein. Steroids. 2008; 73(8): 844-850, doi: 10.1016/j.steroids.2008.04.001, indexed in Pubmed: 18486173.
23. Knaapen MWM, Somers $P$, Bortier $H$, et al. Smooth muscle cell hypertrophy in varicose veins is associated with expression of estrogen receptor-beta. J Vasc Res. 2005; 42(1): 8-12, doi: 10.1159/000082723, indexed in Pubmed: 15604599.

24. Somers $P$, Knaapen $M$. The histopathology of varicose vein disease. Angiology. 2006; 57(5): 546-555, doi: 10.1177/0003319706293115, indexed in Pubmed: 17067976.

25. Zhao MY, Zhao T, Meng QY, et al. Estrogen and estrogen receptor affects MMP2 and MMP9 expression through classical ER pathway and promotes migration of lower venous vascular smooth muscle cells. Eur Rev Med Pharmacol Sci. 2020; 24(3): 1460-1467, doi: 10.26355/eurrev 202002 20205, indexed in Pubmed: 32096196.

26. Kendler M, Makrantonaki E, Tzellos T, et al. Elevated sex steroid hormones in great saphenous veins in men. J Vasc Surg. 2010; 51(3): 639-646, doi: 10.1016/j.jvs.2009.07.128, indexed in Pubmed: 20045626.

27. Beebe-Dimmer JL, Pfeifer JR, Engle JS, et al. The epidemiology of chronic venous insufficiency and varicose veins. Ann Epidemiol. 2005; 15(3): 175-184, doi: 10.1016/j.annepidem.2004.05.015, indexed in Pubmed: 15723761.

28. Asbeutah AM, Al-Enezi M, Al-Sharifi NM, et al. Changes in the diameter and valve closure time of leg veins across the menstrual cycle. J Ultrasound Med. 2014; 33(5): 803-809, doi: 10.7863/ ultra.33.5.803, indexed in Pubmed: 24764335.

29. Jukkola TM, Mäkivaara LA, Luukkaala $T$, et al. The effects of parity, oral contraceptive use and hormone replacement therapy on the incidence of varicose veins. J Obstet Gynaecol. 2006; 26(5): 448-451, doi: 10.1080/01443610600747389, indexed in Pubmed: 16846875.

30. Kostas TI, loannou CV, Drygiannakis I, et al. Chronic venous disease progression and modification of predisposing factors. J Vasc Surg. 2010; 51(4): 900-907, doi: 10.1016/j.jvs.2009.10.119, indexed in Pubmed: 20347686.

31. Sadick NS. Predisposing factors of varicose and telangiectatic leg veins. J Dermatol Surg Oncol. 1992; 18(10): 883-886, doi: 10.1111/j.1524-4725.1992.tb02921.x, indexed in Pubmed: 1430543.

32. Ciardullo AV, Panico S, Bellati C, et al. High endogenous estradiol is associated with increased venous distensibility and clinical evidence of varicose veins in menopausal women. J Vasc Surg. 2000; 32(3): 544-549, doi: 10.1067/mva.2000.107768, indexed in Pubmed: 10957662.

33. Abou-EIWafa HS, El-Metwaly AAM, El-Gilany AH. Lower Limb Varicose Veins among Nurses: A Single Center Cross-Sectional Study in Mansoura, Egypt. Indian J Occup Environ Med. 2020; 24(3): 172-177, doi: 10.4103/ijoem.IJOEM 264 19, indexed in Pubmed: 33746431.

34. Fowkes FG, Lee AJ, Evans CJ, et al. Lifestyle risk factors for lower limb venous reflux in the general population: Edinburgh Vein Study. Int J Epidemiol. 2001; 30(4): 846-852, doi: 10.1093/ ije/30.4.846, indexed in Pubmed: 11511615.

35. Vin F, Allaert FA, Levardon M. Influence of estrogens and progesterone on the venous system of the lower limbs in women. J Dermatol Surg Oncol. 1992; 18(10): 888-892, doi: 10.1111/ j.1524-4725.1992.tb02922.x, indexed in Pubmed: 1430544.

\author{
Adres do korespondencii: \\ Prof. dr hab. n. med. Tomasz Urbanek \\ Katedra i Klinika Chirurgii Ogólnej, Naczyń, Angiologii i Flebologii \\ Śląski Uniwersytet Medyczny \\ ul. Ziołowa 45/47, 40-635 Katowice \\ e-mail: urbanek.tom@interia.pl
}

